\title{
THE EFFECT OF PROFIT GROWTH, FIRM SIZE, AND LIQUIDITY OF EARNINGS QUALITY
}

\author{
Hairul Anam ${ }^{1 *}$, Afrohah ${ }^{2}$ \\ ${ }^{1,2}$ Fakultas Ekonomi, Universitas Balikpapan, Kalimantan Timur, Indonesia \\ *Corresponding author: hairul@uniba-bpn.ac.id
}

\begin{abstract}
This study aimed to examine the effect of profit growth, firm size, and liquidity to the earnings quality. This study used secondary data from the financial statements of pharmaceuticals published by Indonesia Stock Exchange during 2013 to 2017. The research population is all pharmaceuticals company listed in Indonesia Stock Exchange, while the sample in this study were 7 (seven) pharmaceuticals companies. The sampling technique used was purposive sampling method. Method of data analysis using multiple linear regression analysis tools, namely by testing whether there is influence between the research variables consisting of profit growth, company size and liquidity on earnings quality. The result of partially test showed that profit growth had effect to earnings quality, firm size had effect to earnings quality, and the liquidity had not effect to earnings quality. However, the result of simultaneous testing showed that profit growth, firm size, and liquidity had effect to earnings quality.
\end{abstract}

Keywords : Profit growth; Firm size; Liquidity; Earnings quality

Received May $1^{\text {nd }} 2020 \quad$ Revision June $28^{\text {th }} 2020 \quad$ Accepted for Publication July $10^{\text {th }} 2020$

\section{INTRODUCTION}

(Irawati, 2012) describes earnings information as one of the most important parts of financial statements that makes each company competing to increase its profits. However, there are certain parties who do cheat to achieve individual goals of company earnings information. This makes the practice of profit manipulation is often done by company management. This causes a drop of quality in company profits.

(Sukmawati, et al, 2014) explains that earnings quality is a very important matter in a company. Earnings quality is earnings in financial statements that reflect the company's actual financial performance. (Irawati, 2012) states it is possible for earnings growth to have an influence on the earnings quality of a company because if a company has an opportunity to grow its profits, it means that the company's financial performance is good and it is also possible to have an opportunity to grow its earnings quality.

(Sadiah \& Priyadi, 2015) adds that firm size has a relationship with earnings quality because large companies are considered able to produce high profits and high business continuity in improving the company's financial performance. If the level of investor confidence in large companies is high, the higher the profit quality will be. (Sukmawati, et al, 2014) says that liquidity has an influence on earnings quality because if a company has the ability to pay its short-term debt, it means that the company has good financial performance in fulfilling current debt so the company will not practice earnings manipulation.

(Valipour \& Moradbeygi, 2011) also explains that earnings quality arises due to the presence or absence of earnings management. Many large companies suffer from bankruptcy because of lack of earnings management such as Enron, Harry Scarf, and others. So, as a result of this problem, the issue of earnings quality emerges. In addition, other cases also have occurred in Indonesia which happened to manufacturing companies such as the case of PT. Kimia Farma 
Tbk. PT. Kimia Farma Tbk mentioned making a mark up of net profit in 2001. PT. Kimia Farma Tbk said that it made a profit of IDR 132,000,000,000, but after being investigated the company only made a profit of IDR 99,000,000,000 (https://www.tempo.co/).

Based on the background elaborated above, the formulation of the problem in the study is whether profit growth, firm size, and liquidity affect earnings quality on pharmaceutical companies listed on the Indonesia Stock Exchange?

\section{REVIEW OF LITERATURE AND HYPHOTHESES DEVELOPMENT}

\section{Profit Quality}

According to Dechow and Schrand (2004) in (Warianto \& Rusiti, 2014), profit quality is profit that has three characteristics as follows:

1) Accurately reflects the company's current operating performance,

2) Provide a good indicator of the company 's future performance, and

3) Can be a good measure for assessing company performance.

The constructs classification of of earnings quality and measurements is based on how to determine earnings quality which include:

1. The Nature of Time Series on Profit

Earnings quality includes persistence, predictability, and variability. On the basis of persistence, high-quality earnings are earnings that are persistent such as sustainable profits, more permanent, and not transitory. Predictability shows the capacity of earnings to predict certain information, such as future earnings. In this case, high-quality earnings are earnings that have high ability in predicting future earnings. Based on variability, high-quality earnings are earnings that have relatively low variability or smooth earnings.

2. Qualitative Characteristics in Conceptual Frameworks

Earnings quality can be based on a qualitative conceptual conceptual framework (Financing Accounting Standards Board (FASB), 1978). High-quality earnings is profit that is useful in decision making that has characteristics of relevance, reliability, and comparability/consistency. Therefore, the price regression coefficient and stock return on earnings are interpreted as a measure of earnings quality based on the characteristics of relevance and reliability.

3. Relationship to Accrual Cash Earnings

Earnings quality can be measured in various sizes, such as:

a. Cash to Income Ratio

By using a measure of the Cash to Income Ratio, earnings quality is indicated by the proximity of earnings to operating cash flow. Earnings that are closer to operating cash flow indicate higher quality earnings.

b. Changes in total cash accruals

By using a measure of changes in total accruals, high-quality earnings are earnings that have small total accrual changes. This measurement assumes that changes in total accruals are caused by changes in discretionary accruals.

c. Abnormal/discretionary accruals (DA)

The estimation of DA can be measured to determine earnings quality. The smaller the DA, the higher the quality of earnings and vice versa.

d. Estimated relationship between cash accruals 
The close relationship between accruals and cash flow can also be used to measure earnings quality. The closer the relationship between accruals and cash flow, the higher the quality of earnings.

4. Implementation Decision

Earnings quality based on implementation decisions includes two approaches, that is earnings quality is negatively related to the number of considerations, estimates, and predictions needed by the preparation of reports in implementing reporting standards, the lower the earnings quality and vice versa. The second approach, earnings quality is negatively related to the amount of profit taken by management in using considerations to deviate from the standard goal (earnings management). The greater earnings management indicates the lower the earnings quality and vice versa

\section{Profit Growth}

According to (Reyhan, et al, 2014), earnings growth is a variable that explains the company's future growth prospects. Companies that have the opportunity to grow bigger have high earnings response coefficients. This condition shows that the greater the opportunity for the company to grow, the higher the chance for the company to get profits or increase profits in the future. Thus the more rapid growth of the company, the profits generated by the company are getting better quality.

\section{Firm Size}

According to (Harjito, 2012: 45), firm size is the size of assets owned by the company. Basically, firm size is only divided into three categories, namely large companies, medium companies and small firms. The category is based on market capitalization owned by the company.

\section{Liquidity}

According to (Muhardi, 2015: 57), liquidity ratio is a ratio that shows a company's ability to meet its short-term liabilities. In this group there are 3 (three) ratios that are commonly used, such as:

1. Current Ratio

$$
\mathrm{CR}=\frac{\text { Current Asset }}{\text { Current Liabilities }}
$$

The current ratio (CR) is the ratio used to measure a company's ability meet short-term liabilities (short-run solvency) that will mature within one year.

2. Quick Ratio (Acid Test Ratio)

$\mathrm{QR}=\frac{\text { Current Asset-(Inventories+prepayment) }}{\text { Current Liabilities }}$

Quick ratio $(\mathrm{QR})$ is even tougher, it reflects the ability of the company meet current liabilities. This is due to the elements of current assets that are less liquid such as inventories and prepaid expenses are excluded from the calculation.

3. Cash Ratio

$$
\mathrm{CR}=\frac{\text { Cash }+ \text { Marketabel Securities }}{\text { Current Liabilities }}
$$

Another approach to measure the company's ability to meet short-term liabilities is to look at the ratio of cash and cash equivalents in this case the marketable securities of the company. 


\section{Agency Theory}

Based on (Jensen and Meckling, 1976), agency theory is a working relationship between the principal (owner) and agent (manager). As an agent, managers are morally responsible for optimizing principal profits, but on the other hand, managers are also interested in maximizing their welfare. Therefore, it is very likely that agents do not always act in the best interests of the principal, causing agency problems. The agency problem is a problem that arises because of a conflict of interest between the principal and agent so that it will affect the quality of reported earnings.

\section{Hypothesis Development}

It is possible for profit growth to have an influence on the quality of a company's earnings because if a company has an opportunity to grow its profits, it means that the company's financial performance is good and it is also possible to have an opportunity to grow its earnings quality.

\section{$H_{1}$ : The profit growth affects the earnings quality}

The size of the company has a relationship with earnings quality because large companies are considered able to produce high profits and high business continuity in improving the company's financial performance. If the high level of investor confidence in large companies, the higher the profit quality.

\section{$\mathrm{H}_{2}$ : Firm size influences the earnings quality}

Liquidity has an influence on earnings quality because if a company has the ability to pay its short-term debt, it means that the company has good financial performance in meeting current debt so the company does not need to practice earnings manipulation.

\section{H3: Liquidity affects the earnings quality}

\section{RESEARCH METHODS}

\section{Dependent Variable (Y)}

In this study, the dependent variable is earnings quality. Based on (Warianto and Rusiti, 2014), the model used to calculate earnings quality is Modified Jones as follows:

1) Total Accruals $\mathrm{TACC}_{\mathrm{it}}=\mathrm{EBXT}_{\mathrm{it}}-\mathrm{OCF}_{\mathrm{it}}$

2) Non Discretionary Accruals $\mathrm{NDACC}_{\mathrm{it}}=\alpha 1(1 / \mathrm{TAi}, \mathrm{t}-1)+\alpha 2\left(\left(\Delta \mathrm{REV}_{\mathrm{it}}-\Delta \mathrm{REC}_{\mathrm{it}}\right) / \mathrm{TAi}, \mathrm{t}-1\right)+\alpha 3\left(\mathrm{PPE}_{\mathrm{i}} / \mathrm{TAi}, \mathrm{t}-1\right)$

3) Discretionary Accruals $\mathrm{DACC}_{\mathrm{it}}=\left(\mathrm{TACC}_{\mathrm{it}} / \mathrm{TAi}, \mathrm{t}-1\right)-\mathrm{NDACC}_{\mathrm{it}}$

\section{Independent Variable $(\mathrm{X})$}

The independent variables in this study are profit growth, firm size, and liquidity.

a. Profit Growth $\left(\mathrm{X}_{1}\right)$ According to (Warsidi dan Pramuka, 2000) and (Reyhan, et al, 2014), profit growth is measured by the following formula:

$$
\mathrm{PL}=\frac{\text { net profit } \mathrm{t}-\text { net profit } \mathrm{t}-1}{\text { net profit } \mathrm{t}-1}
$$

b. Firm Size $\left(X_{2}\right)$ 
According to (Warianto and Rusiti, 2014), firm size is measured using the natural logarithm of total assets, with the formula:

$$
\mathrm{UP}=\mathrm{Ln} \mathrm{TA}
$$

c. Liquidity $\left(\mathrm{X}_{3}\right)$

According to (Warianto and Rusiti, 2014), liquidity is measured by Current Ratio, with the formula:

$$
\text { Current Ratio }=\frac{\text { Current asset }}{\text { Current liabilities }}
$$

\section{Population and Sample}

The population in this study were 10 pharmaceutical sub-sector manufacturing companies listed on the Indonesia Stock Exchange in 2013-2017. But after conducting the sample selection method using a purposive sampling method, it was obtained a sample of pharmaceutical companies on the Indonesia Stock Exchange of 7 companies. The type of data used is secondary data obtained from the Indonesia Stock Exchange (IDX) in the form of a pharmaceutical company's financial statements from 2013 to 2017.

Tabel 1. Company Samples

\begin{tabular}{lll}
\hline No. & Code & Company Name \\
\hline 1 & DVLA & $\begin{array}{l}\text { PT. Darya-Varia Laboratoria } \\
\text { Tbk }\end{array}$ \\
2 & INAF & PT. Indofarma (Persero) Tbk \\
3 & KAEF & PT. Kimia Farma Tbk \\
4 & KLBF & PT. Kalbe Farma Tbk \\
5 & MERK & PT. Merck Tbk \\
6 & PYFA & PT. Pyridam Farma Tbk \\
7 & TSPC & PT. Tempo Scan Pacific Tbk \\
\hline
\end{tabular}

\section{Data Analysis Method}

The analytical method used in this study is linear regression. Multiple linear regression analysis was used to examine the effect of earnings growth, firm size, and liquidity on earnings quality in pharmaceutical sub-sector manufacturing companies listed on the Indonesia Stock Exchange.

\section{RESULTS AND DISCUSSION Descriptive statistics}

It can be seen from the results of descriptive analysis that the quality of earnings obtained the lowest value of -0.390 , while the highest value of 0.015 . Overall Earnings quality has an average of -0.22140 with a standard deviation of 0.089596 .

The results of the calculation of descriptive analysis shows that the lowest profit growth obtained by -3.645 , while the highest value of 4.637 . Overall profit growth has an average of 0.04745 with a standard deviation of 1.159435 .

The results of the calculation of descriptive analysis can be seen that the size of the company obtained the lowest value of 18.888 , while the highest value of 23.534. Overall, the size of the company has an average of 21.33658 with a standard deviation of 1.380301 . 
The calculation result of descriptive analysis can be seen that the liquidity obtained the lowest score of 1.042, while the highest value of 5.181. Overall liquidity has an average of 2.77684 with a standard deviation of 1.120481 .

\section{Normality test}

Based on the normal probability plot graph, it shows that the normal p-plot graph shows the points spreading around the diagonal line and the distribution is almost in the direction of the diagonal line and the data held looks evenly distributed. That is, the regression model fulfills the normality assumption.

\section{Multicollinearity Test}

Based on the multicollinearity test results, all independent variables have a VIF value of less than 10 (ten) and a tolerance value of more than 0.10 . Thus it can be concluded that in the linear regression model there is no multicollinearity between independent variables.

\section{Heteroscedasticity Test}

Based on scatterplot graphs that the points spread randomly and spread both above and below the number 0 on the $\mathrm{Y}$ axis and there is no clear pattern on the spread of the data. It can be concluded that there was no heteroscedasticity in the regression model.

\section{Autocorrelation Test}

Based on the results of the autocorrelation test in table 4.7 above, it shows that the $\mathrm{d}$ value is 2.238 with a dl value of 1.283 and du 1.653 . DW value is greater than the upper limit (du) and less than (4-du), which is $1.653<2.238<2.334$. It can be concluded that autocorrelation did not occur.

\section{Results of Multiple Linear Regression Analysis}

The multiple linear regression equation is as follows:

$\mathrm{Y}=-0.905-0.038 \mathrm{X}_{1}+0.030 \mathrm{X}_{2}+0.013 \mathrm{X}_{3}$

Based on the equation the constant coefficient value is -0.905 . This value shows that when all the independent variables namely earnings growth $\left(\mathrm{X}_{1}\right)$, firm size $\left(\mathrm{X}_{2}\right)$, and liquidity $\left(\mathrm{X}_{3}\right)$ have a constant value or value equal to 0 (zero), then the dependent variable is earnings quality (Y) will decrease by 0.905 .

The relationship of earnings growth variable $\left(\mathrm{X}_{1}\right)$ to earnings quality variable $(\mathrm{Y})$ can be seen in the regression coefficient value of -0.038 . Thus, if the earnings growth variable $\left(\mathrm{X}_{1}\right)$ rises by one, the earnings quality variable $(\mathrm{Y})$ will decrease by 0.038 , assuming the firm size variable $\left(\mathrm{X}_{2}\right)$ and liquidity $\left(\mathrm{X}_{3}\right)$ are constant (fixed).

The relationship of firm size variable $\left(\mathrm{X}_{2}\right)$ to earnings quality variable $(\mathrm{Y})$ can be seen in the regression coefficient value of 0.030 . Thus, if the firm size variable $\left(\mathrm{X}_{2}\right)$ increases by one, the earnings quality variable (Y) will increase by 0.030 , assuming the variable growth in earnings $\left(\mathrm{X}_{1}\right)$ and liquidity $\left(\mathrm{X}_{3}\right)$ is constant (fixed).

The relationship of liquidity variable $\left(\mathrm{X}_{3}\right)$ to earnings quality variable $(\mathrm{Y})$ can be seen in the regression coefficient value of 0.013 . Thus, if the liquidity variable $\left(\mathrm{X}_{3}\right)$ rises by one, the earnings quality variable $(\mathrm{Y})$ will increase by 0.013 , assuming the variable earnings growth $\left(\mathrm{X}_{1}\right)$ and firm size $\left(\mathrm{X}_{2}\right)$ are constant (fixed). 


\section{Partial Test (t test)}

The partial test results for each independent variable can be explained as follows:

1) The profit growth $\left(\mathrm{X}_{1}\right)$ has a significant level of 0.000 (sig. <.05), so that the profit growth $\left(\mathrm{X}_{1}\right)$ a significant effect on the quality of earnings. Then the hypothesis in this study was accepted.

2) The size of the company $\left(\mathrm{X}_{2}\right)$ has a significant level of 0.001 (sig. $\left.<0.05\right)$, so that the size of the company $\left(\mathrm{X}_{2}\right)$ has a significant effect on earnings quality. Then the hypothesis in this study was accepted.

3) Liquidity $\left(\mathrm{X}_{3}\right)$ has a significant level of 0.213 (sig.> 0.05 ), so liquidity $\left(\mathrm{X}_{3}\right)$ has no significant effect on earnings quality. Then the hypothesis in this study was rejected.

\section{Simultaneous Test (F Test)}

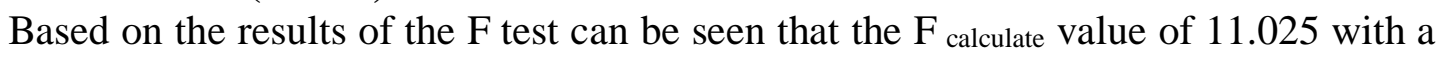
significance value of 0,000 . Because the significance value is smaller than 0.05 and the $\mathrm{F}$ calculate value of 11.025 is greater than the $F$ table $2.91\left(\mathrm{df}_{1}=3, \mathrm{df}_{2}=31\right)$. So it can be concluded that profit growth, firm size, and liquidity simultaneously have a significant effect on earnings quality on pharmaceutical companies listed on the Indonesia Stock Exchange in 2013 until 2017.

\section{Test The coefficient of determination $\left(R_{2}\right)$}

The results of the determination coefficient test show the Adjusted $R$ Square figure of 0.469 or $46.9 \%$. This shows that changes in earnings quality are influenced by earnings growth, firm size and liquidity variables of $46.9 \%$. The rest $(100 \%-46.9 \%=53.1 \%)$ is explained by other variables beyond the 3 (three) independent variables not included in the research model.

\section{CONCLUSION}

\section{The Effect of Profit Growth on Earnings Quality}

Based on the results of the $t$ test on earnings growth shows that partially earnings growth has a significant effect on earnings quality in pharmaceutical companies from 2013 to 2017 with a significance value of 0,000 (less than 0.05 ). The regression coefficient of earnings growth is $-0,038$. A negative sign indicates the opposite relationship between earnings growth and the company's earnings quality. This means that the higher the value of earnings growth, the lower the earnings quality of pharmaceutical companies. (Irawati, 2012), profit growth is included in very low criteria. This means that the company's ability is still low in increasing corporate profits every period. But the company retained its profits for expansion activities which means the company did not manipulate earnings so that the company's earnings information was of good quality.

\section{The Effect of Firm size on Earnings Quality}

Based on the results of the t test on firm size shows that partially the size of the company has a significant effect on earnings quality in pharmaceutical companies from 2013 to 2017 with a significance value of 0.001 (smaller than 0.05). Firm size regression coefficient of 0.030 . A positive sign indicates a direct relationship between firm size and the quality of company profits. This means that the larger the size of the company, the 
higher the quality of earnings at pharmaceutical companies. (Dira \& Astika, 2014), large companies have greater profits and information. Therefore, investors trust larger companies compared to small companies with the hope of obtaining large profits as well. The higher investor confidence, the higher the quality of earnings.

\section{The Effect of Liquidity on Earnings Quality}

Based on the results of the $t$ test on liquidity shows that partially liquidity has no significant effect on earnings quality in pharmaceutical companies from 2013 to 2017 with a significance value of 0.213 (greater than 0.05). Liquidity regression coefficient of 0.013 . A positive sign indicates a direct relationship between liquidity and the company's profit quality. This means that the higher the level of liquidity, the higher the quality of earnings at pharmaceutical companies. According to (Ginting, 2017), liquidity significantly does not affect earnings quality. Liquidity is the company's ability to meet short-term obligations. Liquidity does not guarantee that a company can manage its operations properly, so liquidity does not affect earnings quality.

\section{REFERENCES}

Ananda, R., \& Ningsih, E. S. (2016). Pengaruh Likuiditas, Kepemilikan Institusional, dan Ukuran Perusahaan Terhadap Kualitas Laba (Pada Perusahaan Manufaktur yang Terdaftar di Bursa Efek Indonesia Tahun 2010-2014).Jurnal Ilmiah Mahasiswa Ekonomi Akuntansi (JIMEKA), 1(2),Hal. 277-294 ISSN 2581-1002.

Dira, K. P., \& Astika, I. B. (2014). Pengaruh Struktur Modal, Likuiditas, Pertumbuhan Laba dan Ukuran Perusahaan Pada Kualitas Laba. E- Jurnal Akuntansi , Hal. 64-78 ISSN 2302-8556.

Ghozali, I. (2013). Aplikasi Analisis Multivariate Dengan Program IBM SPSS 21 Update PLS Regresi. Semarang: Badan Penerbitan Universitas Diponegoro.

Ghozali, I. (2014). Ekonometrika. Semarang: Badan Penerbitan Universitas Diponegoro.

Ginting, S. (2017). Pengaruh Profitabilitas, Likuiditas, dan Ukuran Perusahaan Terhadap Kualitas Laba Pada Perusahaan Manufaktur Yang Terdaftar diBursaEfek Indonesia. Jurnal Wira Ekonomi Mikroskil, 7(02), Hal. 227-236 ISSN 2622-6421.

Harjito, D. A. (2012). Dasar-Dasar Teori Keuangan. Yogyakarta: Ekonisia.

Harrison,W.T.,Horngen,C. T.,Thomas, C. W., \& Suwardy, T. (2013). Akuntansi Keuangan International Financing Reporting Standards-IFRS Edisi Kedelapan Jilid 2. Jakarta: Erlangga.

Irawati, D. E. (2012). Pengaruh Struktur Modal, Pertumbuhan Laba, Ukuran Perusahaan dan Likuiditas Terhadap Kualitas Laba. Accounting Analysis Journal, 1(2) , Hal. 1-6 ISSN 2252-6765.

Jensen, M. C., \& Meckling, W. H. (1976). Theory of the Firm: Managerial Behavior, Agency Costs and Ownership Structure. Journal of Financial Economics, 3( 4), Hal. 305-360.

Muhardi, W. R. (2015). Analisis Laporan Keuangan. Jakarta: Salemba Empat.

Reyhan, A., Zirman, \& Nurazlina. (2014). Pengaruh Komite Audit, Asimetri Informasi, Ukuran Perusahaan, Pertumbuhan Laba, dan Profitabilitas Terhadap Kualitas Laba (Studi Pada Perusahaan Manufaktur yang Terdaftar di BEI 2009-2010).JOM FEKON, 1( 2) , Hal. 1-17 ISSN 2355-6854. 
Sadiah, H., \& Priyadi, M. P. (2015). Pengaruh Leverage, Likuiditas, Size, Pertumbuhan Laba, dan IOS Terhadap Kualitas Laba. Jurnal Ilmu dan Riset Akuntansi, 4( 5) , Hal. 1-21 ISSN 2548-5024.

Subramanyam, K. R., \&Wild, J. J. (2013).Analisis Laporan Keuangan Financial Statement Analysis Edisi 10. Jakarta: Salemba Empat.

Sugiyono. (2017). Metode Penelitian Kuantitatif, Kualitatif, dan R\&D. Bandung: Alfabeta.

Sukmawati, S., Kusmuriyanto, \& Agustina, L. (2014). Pengaruh Struktur Modal, Ukuran Perusahaan, Likuiditas dan Return On Asset Terhadap Kualitas Laba. Accounting Analysis Journal, 3(1), Hal. 26-33 ISSN 2252-6765.

Valipour, H., \& Moradbeygi, M. (2011). Corporate Debt Financing and Earnings Quality. Journal of Applied Finance and Banking, 1( 3), Hal. 139-157 ISSN 1792-6580.

Warianto, P., \& Rusiti, C. (2014). PengaruhUkuran Perusahaan,StrukturModal,Likuiditas, dan Investment Opportunity Set (IOS) Terhadap Kualitas Laba Pada Perusahaan Manufaktur yang Terdaftar di BEI. MODUS, 26(1), Hal. 19-32 ISSN 0852-1875.

Widjaja, F. P., \& Maghviroh, R. E. (2011). Analisis Perbedaan Kualitas Laba dan Nilai Perusahan Sebelum dan Sesudah Adanya Komite Pada Bank-Bank Go Public di Indonesia. The Indonesian Accounting Review, 1(2) , Hal. 117-134 ISSN 2086-3802. 